\title{
Management education and the theatre of the absurd
}

\section{INTRODUCTION}

In this paper we adopt a humanities perspective to reflect on the nature of business schools and management education (Vargish, 1991; March \& Weil, 2005; Adler, 2006; McAuley \& Sims, 2009). Business schools have been criticised for becoming the "hired hands" of business (Khurana, 2007) to the detriment of a higher purpose, institutions that champion a utilitarian morality, the shallowness and indeed the dangers of which are revealed in various business scandals and especially the financial crisis of $2007-8$, the effects of which cast a long shadow over today's economic and social landscape. This has led to the criticism that business schools have lost part of their essential "philosophic connection" to issues of humanity and human identities (Augier \& March, 2011: 233-4). We argue that one way to encourage philosophical reconnection is to expand management education's engagement with the humanities (Czarniawska \& Gagliardi, 2006).

A humanities-based approach to management education contests the view that complex management challenges can be easily reduced to administrative control through the collection of defined information and the application of pre-specified prescriptions. Rather, it strives to help managers to see the world in all its rational and emotional complexity, "to evaluate events and persons with greater humility, to view phenomena from a broader perspective, to courageously confront the moral risks and responsibilities involved in doing their job, to rely constantly on a set of values rather than apply algorithms, and to give as much importance to passion as to reason, to wisdom as to competence" (Gagliardi, 2006: 8). For some mainstream scholars, this might seem a counter-intuitive approach but our contention is that a humanitiesbased approach has the potential to create new ways of seeing things that have become routine and taken-for-granted. It might even help us rethink and rebalance our education practices by 
discussing management competence in the context of a broader historical and contextualised perspective.

Incorporating the humanities more explicitly into business schools would, we argue, provide a renewed sense of management education as a humanistic enterprise with an extra dimension uniquely in tune with the challenges of our time. Key to this would be to embrace to what Butler (2005: 82-3) describes as our key existential challenge, to accept that we 'self-narrating beings' capable of rewriting our own scripts rather than conforming to prevailing orthodoxies. Engagement with the humanities, including literature and philosophy, suggests that a key task of management research and education is to create better fictions than those we are currently exposed to and to which we expose our students. The humanities are central to the task of "cultivating humanity" (Nussbaum, 1998) and provide the necessary counterpart to the dysfunctional aspects of modern life that are partly explained by education that focuses on technical competence to the exclusion of asking what it means to be human.

We recommend the drama of the theatre of the absurd as a compelling space for reflection. Critchley (2019: 6) suggests that 'the empty space of the theatre is a way of calling into question the spaces we inhabit and subverting the divisions that constitute social and political space'. We argue that the drama of the theatre of the absurd, associated with dramatists such as Samuel Beckett, Jean Genet, Harold Pinter and Eugène Ionesco, seems uniquely appropriate to reflection on the consequences of a dominant economistic, positivistic way of framing management. The theatre of the absurd prompts key questions about the nature of economic and social life and challenges the assumptions we make, our values and the absurdities these can give rise to. It provides a timely antidote to the fiction of the manager as a highly trained amoral technician and management as primarily a task of rational problem solving (Jouillié \& Spillane, 2015). This challenge seems to us particularly relevant for our challenging times. 
We choose as our main focus the dramatic fiction of one of the theatre of the absurd's leading proponents, Eugène Ionesco. We interpret Ionesco's potential contribution in terms of two of his major themes - how we fill the void of meaninglessness with absurd thought and activity; and 'rhinoceritis', a pernicious and pervasive tendency to conformity that leads to an inability to think critically about the state we are in. We conclude by arguing that we should see absurdity not as an endgame but as an opening to alternative ways of framing the challenges of business and of management education. We structure our argument as follows. We first of all introduce the concept of the absurd as a way of reflecting on the human condition and on our current business and social context. We present a brief overview of the history of business schools and management education, concentrating particularly on criticisms of dominant assumptions about management as a rational activity. We then apply ideas of drawn from the theatre of the absurd to the world of business schools and management education. We conclude by discussing how management educators might respond to a world in which the condition of absurdity is omnipresent.

\begin{abstract}
Absurdity
The term 'absurd' originally meant 'out of harmony' in music, then out of harmony with reason and logic (Esslin, 2001). Honderich (1995: 3) defines the 'absurd' as a 'term used by existentialists to describe that which one might have thought to be amenable to reason but which turns out to be beyond the limits of rationality'. Woodward' (2009: 117) identifies the theatre of the absurd with a crisis of meaning: '[m]eaning is constituted by the meaningconferring activity of consciousness; when this activity is in abeyance, the world appears absurd'. In his classic study of this literary movement, Esslin (2001: xxx) argues that the lens of absurdity provides one of the most important expressions of 'the present situation of Western man' because we live in a world in which the certitudes of previous ages, religious and
\end{abstract}


metaphysical, have been swept away leaving us with a sense of that we surrounded by the forces of irrationality and a growing chaos which we cannot control. Ionesco describes Shakespeare as the king of the theatre of the absurd, citing the view expressed in Macbeth that life is a tale told by an idiot, full of sound and fury, signifying nothing (Kraft, 2012). Peter Brook (1968: 53), one of the twentieth century's leading theatre directors, argues that the theatre of the absurd serves as a powerful reflection of the absence of truth in our day-to-day.

Ionesco argues that there is a growing unwillingness to separate the true from the false because people are carried away by their passions which force them to adopt absurd beliefs. He resists an ubiquitous conformity that he describes in an interview in Le Monde (17 January 1960): 'I have been very much struck by what one might call the current of opinion, by its rapid evolution, its power of contagion, which is that of a real epidemic. People allow themselves to be invaded by a new religion, a doctrine, a fanaticism. ... At such moments ... one has the impression of being confronted with monsters - rhinos, for example'. Indeed, one of the key aims of the theatre of absurd was to create an alternative to what Brook $(1968: 14,39)$ describes as the 'conditioned reflexes' of popular but 'deadly theatre'.

Ionesco's world is peopled with grotesque authority figures who are frequently overcome by their passions and delusions (Lane, 1994: 22). His is a world in which people tend to be 'overwhelmed' by power and by the material world, which makes his work very relevant to an era in which economic success is king and other values are submerged beneath the pursuit of self-interest (Bonnefoy, 1970: 22-3, 135). We focus particularly on Ionesco's work because his world seems to us to have a particular resonance with the world of management as currently enacted and some the key themes developed in his plays - the perennial existentialist theme of 'filling the void' and his analysis of 'rhinoceritis' - seem to us particularly relevant to the life of the business school and management education. 
Management research and education, with a few exceptions, presents an image of rationality and manageability (Morgan, 2006; Grey, 2004). This presents a one-dimensional view of education and of human nature. As Gabriel (1995) points out in his critique of rational models, fantasy is a very powerful if too little acknowledged force in the thinking of organization and emotions all too often prevail over rationality. McCabe (2016) discusses the disorder, irrationality and absurdity at the centre of much organizational life, using Lewis Carroll's (1865) novel Alice's Adventures in Wonderland. This provides a looking glass to examine the pervasive irrationality that exists, even in that supposedly most rational of organisations, the university. More broadly, Andersen (2017: 6-11) describes the condition of contemporary America as having 'passed through the looking glass and down the rabbit hole' so the experience is one of living in a 'Fantasyland' where it is increasingly difficult to disentangle reality, fallacy and fantasy. Ionesco's work, in our opinion, is one of the great depictions of what happens when absurd fantasies come to dominate our lives.

\section{The business school, management education and the theatre of the absurd}

There has been much debate about the nature and purpose of the business school, its research and its management education role (for example, Khurana, 2007; Delves Broughton, 2008; Augier and March, 2013; McDonald, 2017; Parker, 2018). At their beginning in the United States in the late nineteenth and early twentieth century, the business schools that we have tended to see as archetypal, such as Wharton and Harvard, saw their role in terms of the creation and transmission of knowledge for the public good (Bridgman et al., 2016). They were to contribute to an inclusive form of capitalism that would benefit the whole of society, engage with a wide range of stakeholders and justified themselves as a key player in the enlightenment project (Wellmon, 2015). As business schools have grown in size and importance, and particularly since the rise of neoliberalism in the 1980s, we have seen a retreat from the idea 
of the public good and the move to an explanation of human interaction primarily in terms of economic exchange, markets, consumers and a preoccupation with economic individualism and self-interest (Rodgers, 2011).

In their early days, business schools were criticised as little more than trade schools (Khurana, 2007). Reforms of the 1950 s and 1960s focused on changing the knowledge base of the business school by introducing scholarship from the traditional academic disciplines with business relevance to promote 'more rigor, including the greater use of mathematical models and the research findings of psychology and economics and the substitution of formal analyses for rules of thumb' (Augier and March, 2013: 3). While other disciplines survive in the business school, management education has increasingly come to be conceptualised as a technical enterprise with a narrowly focused, instrumental mind-set based on a belief in the primacy and effectiveness of markets and individual self-interest as the paramount value (Ferraro et al., 2005; Kay, 2004; Davis, 2009; Hendry, 2006).

Technical skills are seen as central to what is taught in business schools, especially the ability to conduct company valuations (Hubbard, 2006). This reflects an unholy alliance of economics and finance has become a new form of 'state religion' (Davies, 2009: vii). Managers are to be judged only as efficient resource allocators and profit maximizers. Business practices that distort the rational efficiency of markets, such as paying employees more than necessary or charging customers less that you can, are to be eradicated (Davies, 2009: 81). Such are the lessons of much management education, reflecting the growing dominance since the 1980 s of neoliberalism, the key focus of which is to reduce all aspects of our existence to an exercise in markets and competition in which economic rationality is supposedly king, 'without metaphysical appeals to the common good... The price paid for this economic imperialism is that ... the language of 'price', 'competitiveness' and 'efficiency' [becomes] the lingua franca of public ... discourse' (Davies, 2017: 190; 197). 
Starkey and Tiratsoo (2007) suggest that business schools have increasingly become too much businesses at the expense of their education role, university cash cows whose main purpose is to deliver 'margin'. Alvesson and Spicer (2013: 213) argue that the 'metaphysics' of the market organize and legitimates 'stupidity', which manifests itself in the refusal to use critical thinking to reflect on what you believe and teach. Important questions about ideals, values, ideals, and alternative representations of reality are marginalised. Critical management has opposed the prevailing orthodoxy but remains marginal as the mainstream disciplines tighten their iron grip (Reed \& Burrell, 2018). Economists and finance scholars become the power elite of the business school, claiming to present the real truth about the way the world works, promising their students the royal road to wealth appropriation (Davis, 2009). Their privileged position is cemented by the award of Nobel prizes. The language of financial economics and values, primarily shareholder value and latterly private equity, permeate students' views of the world.

A key target of Ionesco's drama is 'bourgeois mental sclerosis, on the one hand; the tyrannies of political regimes and directions on the other' (Ionesco, 1963: 148). The abuse of language as a weapon of power and as a form of obfuscation is central here. Ionesco offers a perspective on education as the (ab)use of power and position to impose a particular worldview. In his play The Lesson, he focuses on the arrogance and the abuse of power of education as a medium of enforcing conformity to a particular worldview. The Lesson depicts the dark side of education in which the mastery of the teacher leads him/her to try and impose particular rules on the rest of society, rules which lead to extreme negative results for his/her pupils. The definition and the control of the use of language is a key part of this strategy (Lamont, 1993: 56-7). At the start of the play, a pupil arrives for a lesson with her professor. At first, the lesson progresses normally but gradually the professor becomes increasingly frustrated with the inability of the student to learn. The play seems to start as a parody of an over-pedantic approach to education 
but soon turns more sinister. The pedant becomes a tyrant, desperate to impose his learning on an unreceptive pupil, rendered incapable of learning by the dynamics of the lesson.

The pupil, we learn, is preparing for a 'total doctorate' composed of mathematics, linguistics and philology but proves lacking in certain skills. For example, she is able to add to infinity but is unable to subtract and divide. The professor informs her that she will have to be content with 'a partial doctorate'. The focus of the lesson shifts from mathematics to philology, against the advice of the other character in the play, the maid, who warns that philology will lead to 'calamity', which indeed it does. The professor finally murders the poor student when he can no longer contain his rage at her inability to learn what he wants her to. Education functions as a form of 'vampirism' (Bonnefoy, 1970: 103), sucking the individuality out of the pupil.

The tragic end of this 'comic drama' ensues with the maid helping to get rid of the student's body. Then we learn that this is not an isolated incident. Indeed, it is the latest in a long line of murders of his pupils committed by the professor. The Lesson captures the attempt to impose knowledge (what the teacher knows) on the pupil. Education and logic are synonymous with oppression, the urge to 'arithmetize' leads to murder, justified because the student was disobedient and unable to learn, a bad pupil. 'For the Professor words are just a means of taking possession of a human being and through all his verbiage and word-play, underneath the superficial culture, there is instinctual reality which this language masks or unmasks' (Ionesco, 1972: 5). This raises serious questions about our own attitude towards teaching and our purpose in providing the kind of management education we currently desire for our students, an issue we will return to later. The play also captures, thankfully through exaggeration, the emotions that the experience of teaching can trigger in us. We acknowledge in our own institutions that teaching can sometimes (more often than we would like) be a struggle as we strive to cope with the large classes that are the norm in many business schools and classes where the vast majority of the students are not native English speakers. We also acknowledge the negative emotions 
that can arise from the expectation that we are there to provide technical expertise that comes complete with its own problem solution (a formula, a model, a theory) rather than to stimulate critical reflection on what too often in the practical management literature seem too easy answers. Teaching in the business school does remind us of Sisyphus pushing that rock up the mountain and rarely reaching the summit.

How should we characterise the current state of management education? We suggest that when it is not conducted with a degree of critical self-reflection it is unfortunately similar to the world depicted by Ionesco. Students are taught to see the world in a particular way. Lambrechts et al., (2011: 143) summarise this process when they depict the typical business school as somewhere 'inexperienced students are over-trained in analyses and quantification by professors with limited real-world experience, who strictly adhere to the scientific model of science delegitimizing pluralism in knowledge-production forms, acting completely in line with what their incentive and promotion system rewards, away from practitioners, considerably neglecting the development of important interpersonal management skills'.

\section{Filling the void}

The theatre of absurd is preoccupied with the idea of the 'void', the struggle to find meaning in a world empty of sense. The absurd 'is born of nihilism, out of existentialism, the inevitability of death and lack of meaning (Cornwell. 2006: 5). How do we create meaning to fill the void of meaninglessness? We tell ourselves stories, create fictions that we come to believe capture the essence of life. In one of its most famous plays, the main characters spend their time 'waiting for Godot' (Beckett, 1954) despite growing evidence that Godot will not arrive and almost certainly does not even exist. Godot looms large over contemporary life. We 
are all waiting for our own Godots and a key task of management in both the private and public sector is to convince us that its Godot is more real than the alternatives.

Managers and management education, from an absurd perspective, thrive by filling our lives with fantasies we end up hostage to. This is reflected in a bizarre inflation of language that now affects the whole of higher education. Alvesson (2013) examines a pervasive triumph of ephemerality in higher education generally, with business schools as a prime example, in which grandiosity is pursued and dubious claims of 'excellence' and being 'world-class' proliferate. Marketing takes centre stage at the expense of substance with image 'boosting/manipulation', otherwise justified as rebranding or brand repositioning, and consumerism devalues traditional education ideals (Kirp, 2003). Augier and March (2013: 282; 180) argue that business elites have been increasingly educated as 'experts in the management of speculation', motivated by 'free market greed'. Finance faculty teach them to pursue 'fool's gold' (Tett, 2009). Foroohar (2016) argues that business schools graduates are 'takers', out for themselves, not 'makers' interested in contributing to the public good. Using a Cartesian allusion, the raison d'être that defines too much business education, what is taught and what students aspire to, is 'I make money therefore I am'. The idea of personal enrichment fills the void of meaning for students in a consumerised and marketized economy.

The heroes of business schools are the business leaders who have made the biggest financial return. In Delves Broughton's account (2008) of his Harvard MBA course, it is the giants of private equity and hedge funds who receive a rapturous welcome when they feature as visiting speakers. This illustrates the shift in business school purpose that Khurana (2007) eloquently describes as a shift from 'higher purpose' to becoming the 'hired hands' of those businesses that pay the highest dollar. The MBA is marketed as a 'golden passport' (McDonald, 2017) enabling entry into an exclusive elite of masters and mistresses of the universe. The world is 
increasingly managed by reference to a positivistic fantasy that all life can be adequately represented by models that both capture the essence of a system and can be used deterministically (Jouillié \& Spillane, 2015: 240). The measure becomes the goal.

In education, metrics create their own purpose that defines the factors that are considered important. In Ionesco's play The Bald Soprano the Captain of the Fire Brigade arrives unexpectedly at the home of Mr. and Mrs. Smith with orders 'to extinguish all the fires in the city' but there is no sign of fire in the Smiths' house, 'no smell of anything burning'. Questioned about why he is so passionate about discovering fires, he tells them that things have been going very 'poorly' for him at work and he needs to persuade the population of his area that they need to start more fires: 'There's been almost nothing, a few trifles - a chimney, a barn. Nothing important. It doesn't bring in much. And since there are no returns, the profits on output are very meagre' (Ionesco, 1958a: 27-28). Here we are reminded of business practices based on transforming desires and the principle of planned obsolescence. Companies increase profits by stimulating demand for products designed for the shortest shelf lives. In fast fashion, for example, consumers are persuaded that they need to replenish their wardrobes on a regular basis and products are manufactured not to last.

In academia we are not exempt from such pressures and have experienced a growing proliferation of output measures. Like Ionesco's fire chief, faculty fill the void with metrics in what Alvesson (2013) calls a 'triumph of emptiness'. Business schools have become obsessed with a proliferation of rankings (Bachrach et al., 2017) in which students' achievement is measured primarily in terms of the student return on investment, expressed in salary earned, rather than actual management achievement. There is also a growing obsession with accreditation with, in the UK, the fetish of triple accreditation (AACSB, EQUIS and AMB), being seen, bizarrely in our view, as somehow an ultimate benchmark of reputation. 


\section{Rhinoceritis}

We fill voids by adopting and adapting ourselves to shared stories. Management education is a form of worldmaking (Goodman, 1978). It aims to convince our students of the truth of a particular way of seeing and making the world. It seduces with the promise of entry to the elite world of the manager and, ultimately, the business leader. In this sense it tends to be conformist education, an exercise in reinforcement of a particular world view. Much of management education is based upon creating a relatively one-dimensional, 'universal', 'international' type of manager (Elliott \& Robinson, 2011). The growing dominance of the language of numbers and finance as the basis for management which excludes any considerations beyond the economic has resulted in a world dominated by the markets (Davis, 2009). Our notion of civilization, at least in the West, is now dominated by the economic power and the soft (cultural) power, including ideas about management culture, of the United States to the extent that even French critics such as philosopher Régis Debray (2019) write about 'how we all became American': 'International bodies no longer ask emerging peoples to Europeanize, but rather to Americanize. ... while in 1919 there was a European civilization, with American culture as a variant, [now] there is an American civilization, in which European cultures seem ... at best minor variations. ... One patron of humanity, in both senses of the word ['employer' or 'patron saint'], has expelled another' (Debray, 2019: 29).

The theatre of the absurd abhors conformism for its own sake. A key concept dramatized by Ionesco as the root of much absurdity is 'rhinoceritis', an extreme form 'of conformity which knows no bounds, no boundaries .... a pernicious disease of epidemic proportions ... enslaved by a mass of prejudices which take on the appearance of a terrible, warped lucidity' (Bonnefoy, 1970: 139). For Ionesco, being bourgeois is synonymous with being 'simply the man of slogans, no longer thinking for himself, but repeating ready-made truths - hence dead truths - 
which others have imposed upon him' (Ionesco, 1963: 142). The play Rhinoceros (Ionesco, 1958b) is his most developed exposition of this idea. In it the existing order is turned upside down when people start growing horns on their foreheads and turning into rhinoceroses. Only one person, Bérenger, resists. The lesson is that the human mind, unless it adopts an active strategy of resistance, will succumb to the herd instinct, our sense of humanity overcome by the 'animal spirits' that Akerlof and Schiller (2010) remind us are an integral part of market behaviour.

Ionesco links rhinoceritis to the veneer of civilization that proves skin-deep in times of crisis. 'I have the impression of being with extremely polite people ... Suddenly something breaks down, gives way and the monstrous character of men appears or rather the scene becomes strangely unknown and men and the scene thus perhaps reveal their true nature' (cited Bonnefoy, 1966: 167). From this perspective we suggest that management education is too often an exercise in rhinoceritis. Business school graduates, such as accountants, are taught to embrace and conform to the languages and the codes of their discipline and to reproduce this world in their business roles (Brooks, 2018). Conformity is about language and identity. Ackoff (2002) suggests that the first contribution of management education is to teach students a vocabulary that enables them to talk with conviction about subjects they do not really understand. Confidence trumps competence. Augier and March (2013: 273-4) describe how MBAs appear to those outside the business school: 'A standard perception on a university campus (outside of the business school) is that MBA students arrive on a campus looking and acting more or less like people; within two weeks, they are easily recognizable as MBA students, using MBA-speak to communicate and sharing mannerisms, dress, and understandings that decisively distinguish them from others'. They adopt a new identity consistent with the ideology of business and management they are taught, a main tenet of which is that life is best managed by appealing to self-interest and monetary incentives. Delves 
Broughton's (2008) describes his time at Harvard Business School as a form of 'aggressive socialization' into becoming a breed apart, tempered in the flames of the 'cauldron of capitalism'. Leavitt (1989: 39) argues that 'we have built a weird, almost unimaginable design for MBA-level education ... distorting [students] into critters with lopsided brains, icy hearts and shrunken souls', actors, in short, ideally suited for business as theatre of the absurd.

And it is not just students who are aggressively 'socialised'. In Anteby's (2013) account of faculty life in a top business school a pivotal moment is the visit of the 'executive clothier' - to advise on dress codes and measure faculty for the 'proper dress' (of nonsolid dark colors). This scene would not be out of place in the theatre of the absurd. Faculty struggle with more than just dress codes. One of the most startling examples of rhinoceritis in which faculty share is the lemming-like rush to publish. A key challenge faculty face is 'publish or perish'. The price of journal publication is too often that authors compromise on challenging accepted research norms, fearing rejection and career damage, reduced to 'eunuchs' (Brown, 1995: 698). Being published becomes more important than scholarship. Faculty need to be tough, thick-skinned, like rhinoceroses, to survive. They face a Darwinian struggle for survival in what can be a cruel academic world. In top schools, faculty who do not make the cut and fail the ferocious tenure track process are speedily vanished. This is akin to Russian roulette, with rather worse odds. In the top schools, only one in six survives the tenure process. Professional moving specialists 'routinely and rapidly ... eras[e] traces of their past occupants' (Anteby, 2013: 120), rather like the maid hiding the bodies in The Lesson.

Faculty in research-led schools fill much of their time pursuing journal publications (Anteby, 2013), their own personal Godot. Journals have created their own absurd ecosystem. Davis (2015), himself editor of a leading journal, suggests that the journal incentive system is 'broken'. Referring to the $8000+$ articles published in management journals each year, he argues that we reward the wrong kinds of research, novel but relatively insignificant, often 
driven by 'regressionology'. Proxy measures of impact, such as citations, are easily 'gamed', with little evidence of cumulative knowledge development. Davis compares the state of management research to the Winchester Mystery House in San Jose, with many rooms but no overarching common purpose. Management research, he argues is more like a mystery house than a cathedral. He draws on Shakespeare's metaphor of 'full of sound and fury' to describe too much management research. In the original (Macbeth) the quotation concludes 'signifying nothing'.

Business school rhinoceritis is fuelled by the 'perversion' of 'journal list fetishism' and the 'rankophilia' so beloved of many faculty and business school deans (Willmott, 2011). How have business schools become like this? Bennis and O'Toole (2005) suggest that the 'dirty little secret' in today's business schools is that they are organized to serve faculty's research interests with little regard for the needs of other stakeholders. The incentive system surrounding research has been compared to the 'cobra effect' (Anonymous Academic, 2018). During British rule in India, officials in Delhi wanted to curb the population of cobras. They offered an incentive for each cobra killed. Some Delhi inhabitants reacted by breeding cobras so that they could kill them and collect the reward. The officials stopped the incentive scheme. Those who had been breeding cobras set them free causing the cobra population to explode. Business school culture is too often a 'pungent mixture of cynicism and paranoia': 'Scholarship is ... merely a way of keeping the anxiety at bay of the overwhelming demands placed on us by the Big Other of Excellence in teaching and research' (Cederström and Hoedemaekers (2012: 233).

\section{Discussion: Engaging absurdity}

Savage et al. (2018: 989) argue that we need to consider 'organizations as fictions'. They apply this argument to different fictions of the university based on notions of identity and desires for 
the future. Business schools are a potent site for various fictions, the fictions we sell our students, and the fiction we use to make sense of and to organise our own lives within them. When one story becomes inadequate the task is to create a different, more compelling fiction. We face "the choice to accept the fiction as sufficient for use in the ongoing and continuous mimetic cycle, or to reject this fiction as lacking sufficient similitude or semblance of truth to be used in this configuration' (Savage et al., 2018: 988). In this process management education can be reframed as a constructive, critical project in releasing students from the constraints of prevailing economic orthodoxies in a world under the thrall of neoliberalism (Davies, 2017: 87).

We recommend the theatre of the absurd as a powerful reflection of a world in which passions seem to have gained an upper hand over reason and reflection. In Ionesco's work we are presented with a world stripped of the veneer of civilisation and communication is thwarted by 'clichés, empty formulas ... the fossilization of language ... the personification of accepted ideas and slogans' driven by emotion not reason (Esslin, 2001: 130; 141). The second act of Ionesco's play, The Killer, opens with conversations heard offstage, a concierge discussing philosophy, a teacher giving a nonsensical history lesson, voices from the right and from the left, and a manager discussing a radical new approach to making employees more efficient: 'Our fifty-eight delivery boys waste too much time urinating. Five times a day, on average, they interrupt their deliveries to satisfy a personal need. The time is not deducted from their wages. They take advantage of this, so they've got to be disciplined; they can make water in turn once a month for four and a half hours without interruption. That will save all the coming and going, which sends up our costs' (Ionesco, 1960: 51). 'Insane bureaucracy' is a 'prime target' of the drama of the absurd (Cornwell, 2006: 149).

Ionesco's work fiercely lampoons those who 'repeat the truths that others have imposed upon him, ready-made and therefore lifeless. In short ... a manipulated man' (Ionesco, 1964: 67). 
Truth claims are too often revealed to be irrational. Neoliberal claims for markets as the basis for a better world seem rather over-stated. We embrace or persuade others to embrace such truths to fill a void of purpose. These 'zombie' ideas (Quiggin, 2012) survive because of the virus of rhinoceritis. As Esslin (1980) argues, the lens of absurdity provides an important perspective on the human condition as we currently experience it where our previous certitudes have been swept away leaving us with a major challenge in making sense of the world we now inhabit.

We have suggested that the world of management is increasingly impacted by Americanization reflected in the dominance of Homo economicus. 'In the beginning was the Word. In the bginning will be the Number. ... what part of our life can avoid calculation?' (Debray, 2019: 33). The dominant philosophy of management is positivism according to which standardization and replication are the ne plus ultra of knowledge. The result is that in the name of calculability, intentionality, freedom and responsibility had to be taken out of all equations or law-like generalisations taught to management students and that employees or consumers be levelled down to the status of lifeless economic agents' (Joullié \& Spillane: 2015: 319). Leading business schools claim to be in the business of manufacturing morals (Anteby, 2013) but the kind of morals they stand for and the leaders they educate have been increasingly criticised, not least in the aftermath of the financial crisis of 2008.

Of course, there were other parties besides business schools responsible for the financial crisis. Tett (2009) examines the roles of regulators, senior industry executives, consultants as well as the role of business school graduates. Podolny (2009), former Dean of Yale Management School, holds business schools at least partly responsible for the crisis because the education they offered had corrupted the moral sense of their students, many of whom aspired to and became Wall Street executives. This adds weight to Ghoshal's (2005: 75-6) prediction before the financial crisis that bad 'ideologically inspired amoral' management theories were 
'destroying' good management practice. These theories were based, Ghoshal (2005: 79) argues, on a 'pretense of science', fantasies of agency and ownership, based on the application of reductionist scientific methods that are incapable of capturing the complexities of social life. Ghoshal (2005: 80) critiques Friedman's (1953) influential claim that we do not need to worry that 'the assumptions of our theories [such as assumptions of efficient, rational markets] do not reflect reality; what matters is that these theories can accurately predict outcomes'. Ghoshal adds, 'irrespective of how the assumptions may look from the perspective of common sense', even if these assumption seem to us absurd. Even after the financial crisis, a former Governor of the Bank of England (King, 2010) still describes the management practices of the financial services industry as 'absurd'.

A theatre of the absurd perspective teaches us revise our representations of the world as more absurd than rational, with management and management education implicated in the world's absurdities. Hendry (2006: 268) argues that the business school curriculum is dominated by 'naïve' rationalizations and techniques associated with business functions such as finance, accounting and marketing. Its core image of the manager as 'bureaucratic technician' is a socially and morally reductionist one, arising from an unholy alliance of economics and finance. Criticisms of business schools and management education share the same concerns of critics of current business and management practices. The philosopher Richard Rorty (1998) captures the essence of the critical position when he argues that the key challenge we face as educators and as citizens is the growth of inequity, injustice, cruelty and fantasy masquerading as truth. Business schools are accused of being complicit in the marketization and individualization that, according to Rodgers (2017), are 'fracturing' the very foundations of mutuality upon which our society and our economy depend.

The theatre of the absurd drew its inspiration from the philosophy of existentialism and one of the lessons we draw from our engagement with this body of work is that need to make 
philosophy more central to management education. Here we recommend the pioneering work of Jouillié and Spillane, (2015) as a recommended text. They draw from their study of existentialism a renewed emphasis upon 'an intersubjective understanding of human relationships', a focus on 'autonomy, empathy, subjectivity' and the lesson that one of the main purposes of education is to maximise the exercise of responsible freedom (Jouillié \& Spillane, 2015: 252-3). Sartre (1960) describes Albert Camus as the 'Descartes of the Absurd'. For Camus and his seminal work on absurdity, The Myth of Sisyphus, the ancient Greek myth of Sisyphus captures the essence of the human condition. For his sins against the Gods, Sisyphus is condemned to push a boulder up a mountain only for it to roll back down as he reaches the summit, over and over again, forever. Camus (2000: 87) compares Sisyphus to our current predicament: 'The workman of today works every day in his life at the same tasks and this fate is no less absurd'.

But while his work presents an argument for the recognition of the reality of the absurd as a key aspect of the human condition, Camus also argues that reflecting on absurdity can provide the means to proceed beyond nihilism. Camus (2000: ix) describes The Myth of Sisyphus 'as a lucid invitation to live and create, in the very midst of the desert'. Rather than the absurd being taken as a conclusion, Camus argues that it should be considered a starting point for thinking about how to build a better world. In what he describes as 'the cruel mathematics that command our condition', Camus identifies a deep and damaging gap between what we think we know and what we really do know. The concept of a 'universal reason' at this stage of our thinking about how best to organize our world, the deterministic vision that creates the categories of thought and science that supposedly explain everything are, he suggests, 'enough to make a decent man laugh' (Camus, 2000: 14-17).

The challenge is to work out a strategy, intellectual and practical, for developing a viable philosophy, based on a shared sense of meaning, in the face of a pervasive crisis of meaning, 
to undermine the forms of rhinoceritis that afflict us. 'Beginning to think is beginning to be undermined' (Camus, 2000: 6). It would be naive us to conclude by arguing that the way forward is clear but we do think an important first step in rethinking management education is to argue for greater engagement with the humanities that seem to us best placed to turn the absurd into something more positive. Our own theatre of the absurd requires new ways of thinking and new ways of framing engaged management research to overcome the limits and the damage caused by current ways of thinking about business and about society, to challenge the solipsism of some of our core disciplines. What are we to do? In the words of Choubert, a character in Ionesco's Victims of Duty: 'The government's urging all ... citizens ... to cultivate detachment. According to this, it's our last hope of finding an answer to the economic crisis, the confusion of the spirit and the problem of existence'. Camus suggests that detachment will only make things worse.

A lesson we draw from our engagement with the theatre of the absurd is we need to include (more) literature and philosophy in business schools' core curricula. This would provide students with a necessary historical context for trying to better understand our present and how mainstream management disciplines reflect disputes about what we know have their roots in particular traditions of Western thought and illustrate their manifestation in mainstream management disciplines. Philosophy teaches critical reflection about the language and concepts we use, not one-dimensional prescription: 'The critical evaluation of assumptions and their outcomes brings about the awareness of alternatives ... Philosophy ... is about meaning in general and the meaning of human existence in particular ... one of the best preparations for responsible civic life' (Jouillié \& Spillane, 2015: 316-318). The humanities are essential in what Nussbaum (1998) describes as cultivating our humanity through critical thinking. We also recommend incorporating social anthropology into the curriculum for example Wrangham (2019) to discuss the tensions in human evolution between our tendency to aggression, 
competitiveness and violence and our desire for social tolerance. We use Peters (2012) to discuss how we can better manage the tensions between our attempts to be rational and our evolutionary animal inheritance to better understand our humanity.

Readers might ask what we would advise colleagues wishing to design new degrees or specific modules based upon the humanities. We ourselves introduce some of the ideas we have discussed, for instance, the negative effects of power and the potentially dysfunctional relationships between leaders and followers that can create "rhinoceritis", into our strategy and leadership modules. We strongly recommend that the philosophical foundations of management thought and practice should form the basis of a core module on management degrees, undergraduate and postgraduate. There already exists an ideal text to form the basis for such a module, namely Jouillié and Spillane's (2015) The Philosophical Foundations of Management Thought. This constitutes a provocative stimulus to critically consider the philosophical underpinnings of management thought, ranging across topics such as Managing Rationally, Managing Empirically, Positivism, Romanticism, Psychoanalysis and Existentialism.

Our second suggestion is to develop the humanities-based approach to leadership, pioneered by James March (March \& Weill, 2005). March uses examples from literature such as Shakespeare and Tolstoy to enable deep inquiry into the nature of leadership that is impossible if we just use mainstream journal research on this topic. Shakespeare is an essential part of the curriculum for his unparalleled insights into human nature, for example, in his depiction of leaders who put their own pleasure and self-interest above any concern for the public interest and for the fundamental questions he poses about the lust for and the exercise of power. He poses fundamental questions such as "Why would anyone ... be drawn to a leader manifestly unsuited to govern, someone dangerously impulsive or viciously conniving or indifferent to the truth?” (Greenblatt, 2018: 2). Part of March and Weil's 
argument (2005) is that literature helps us come to terms with an "absurd universe" and enables us to deal with "pessimism without despair". This seems to us particularly relevant to our challenging times and the theatre of the absurd is an obvious addition to the March canon and also provides an interesting counterpoint with March's more mainstream perspective.

Of course, to affect this change will mean that other parts of the curriculum will have to change. This is unlikely to be popular among some of our colleagues. Hopefully they can be convinced of its necessity but, failing that, it might well be that the current co-location of so many disparate disciplines and faculties under the one banner 'business school' is no longer desirable. It is very likely the language of management and the language of economics and finance are not compatible. Stigler (1992) made this point in relation to the co-existence of economics and law: 'The difference between a discipline that seeks to explain economic life (and, indeed, all rational behaviour) and a discipline that seeks to achieve justice in regulating all aspects of human behaviour is profound. This difference means that, basically, the economist and the lawyer live in different worlds and speak different languages' (Stigler, 1992: 463). Perhaps one consequence of our argument is that we need to divide business schools into separate schools - management schools and schools of economics, finance and accounting? The question we should ask in considering what to include in our curriculum and as a touchstone of research value is: how does it help us and our students in 'cultivating our humanity'?

Koris et al. (2017: 174) argue that 'for a business school to 'legitimately' position itself as a university and rightfully provide academic degrees, it should, in addition to providing students with a profit-maximizing toolkit, deliver a wider educating balancing different (human, moral, environmental, social ...) perspectives'. If we make the humanities our touchstone we accept that management education should encompass not just technical knowledge but also personal growth, defined by Aristotle as growth in 'virtues or character strength' (Murcia et al., 2018: 
579-581). Making the humanities a key aspect of management education means that we will we need to take more seriously the role of the imagination and fiction in our economic and social life. We are more conditioned by our fantasies than many would like to believe. In recent times our lives have been increasingly framed by economic theories and institutions based on their own unique fantasy elements based upon a quasi-science of calculability.

Beckert (2016) argues that our current society functions not according to tradition but according to 'imagined futures', 'fictional expectations' of how we think the world should be. 'Actors, motivated by an imagined future state, organize their activities based on this mental representation and the emotions associated with it. ... Fictionality, far from being a lamentable but inconsequential moment of the future's uncertainty, is a constitutive element of capitalist dynamics, including economic crises. ... Capitalism needs the evocative overload of fictional expectations in order to operate' (Beckert, 2016: 9; 12). We need to develop a greater range of fictions about the future that deal with critical situation in which we find ourselves (Žižek, 2010). Too many business schools exhibit an anti-humanities bias. Harvard MBAs were actually advised in The HBS Survival Guide, ‘[d]on't bring any books from literature or history classes'(Delves Broughton, 2008: 41). Students become stuck in an eternal present without the resources to imagine the future differently. The 'perverse effects' of this are described by Debray (2019: 84). "[T]he historicity of the human condition is denied, a conjectural and media-driven geopolitics is established, both unrealistic, and set for failure.' A key historical issue at to consider is whether the future will inevitably involve further 'Americanization', with its core economic doctrine' (Debray, 2019: 87), what are the alternatives and what changes in management education we will need to achieve them.

Camus (1957), philosopher of existentialism and the absurd, emphasizes two key responsibilities - the service of truth and the service of liberty - which seem to us to apply to our responsibilities as management educators. The challenge is to (re)conceive of education 
and the university as a space for thinking not as a consumer retail park (Collini, 2017). The arts and the humanities have a key role to play. One of their major potential contributions is to help us understand our deepest anxieties and desires in a constructive manner and in search of a shared sense of what it means to be human (Nussbaum, 1998). In philosophy, for example, Rorty (1992: xiv), argues that we need 'shared social effort ... to make our institutions and practices more just and less cruel'. Business schools can choose to focus on developing selfnarrating beings (Butler, 2005) capable of more humane forms of understanding and action, educated to create better stories informed by critical engagement with our past and present, or they can continue to play their role as rhinoceroses in their own theatre of the absurd.

\section{Acknowledgments}

We would like to express our gratitude to three anonymous reviewers for their contribution to the development of the paper. We would also like to acknowledge the generous sharing of ideas on French literature with Professor Armand Hatchuel of Paris Mines-Tech at an early stage of the paper. 


\section{References}

Akerlof, G.A. and Shiller, R.J. (2010) Animal Spirits: How Human Psychology Drives the Economy, and Why It Matters for Global. Princeton: Princeton University Press.

Ackoff, R.L. (2002) 'Interview by Glenn Detrick'. Academy of Management Learning and Education.

Adler, N.J. (2006) 'The arts and leadership: Now that we do anything, what will we do?' Academy of Management Learning and Education, 5:466-499.

Alvesson, M. (2013) The Triumph of Emptiness. Oxford: Oxford University Press.

Alvesson, M. and Spicer, A. (2012) 'A stupidity based theory of the organization'. Journal of Management Studies, 49: 1194-1220.

Andersen, K. (2107) Fantasyland. How America Went Haywire. A 500-Year History.London: Ebury.

Anonymous Academic 2018 Performance-driven culture is ruining scientific research. The Guardian, 2/23/2018 (https://www.theguardian.com/higher-educationnetwork/2018/feb/16/performance-driven-culture-is-ruining-scientific-research)

Anteby, M. (2013) Manufacturing Morals. Chicago: Chicago University Press.

Augier, M. and March, J.G. (2013) The Roots, Rituals and Rhetorics of Change. North American Business Schools After the Second World War. Stanford: Stanford Business Books.

Bachrach, D.G., Ammeter, D.B., Blackburn, R., Brown, K.G., Burke, G., Callahan, T., Chen, K.Y., Day, V.H., Ellstrand, A.E., Erekson, O.H., Gomez, J.A., Greenlee, T., Handfield, R., Loudder, M.L., Malhotra, M., Petroni, K.R., Sevilla, A., Shafer, S., Shih, M., Voss, D. (2017) 'On academic rankings, unacceptable methods, and social obligation of business schools'. Decision Science.

Beckert, J. 2016 Imagined Futures. Fictional Expectations and Capitalist Dynamics. Harvard: MA: Harvard University Press.

Beckett, S. (1954) Waiting for Godot. New York: Grove Press.

Bennis. W.G. and O’Toole, J. (2005) 'How business schools lost their way'. Harvard Business Review, 83(5): 96-104.

Bok, D. (2103) 'Comment on 'The Business of Business Schools' (by Robert Simon)'. Capitalism and Society, 8, 1, Article 5. Academy of Management Review.

Bonnefoy, C. (1966) Entretiens avec Eugène Ionesco. Paris: Pierre Belfond

Bonnefoy, C. (1970) Conversations with Eugène Ionesco. London: Faber \& Faber.

Brook, P. (1966/2008) The Empty Space. London: Penguin. 
Brooks, R. (2018) Bean Counters. The Triumph of the Accountants and How They Broke Capitalism. London: Atlantic Books.

Brown, S. 1995 'The eunuch's tale: reviewing reviewed'. Journal of Marketing Management 11: 681-706.

Butler, J. (2005) Giving an Account of Oneself. New York: Fordham University Press.

Camus, A. (1957) Banquet Speech. (Albert Camus' speech at the Nobel Banquet at the City Hall in Stockholm, December 10) www.nobelprize.org/nobel_prizes/literature/laureates/1957/camus_speech.html (accessed 9 January, 2017).

Camus, A. (2000) The Myth of Sisyphus London: Penguin Classics. (First published as Le Mythe de Sisyphe, 1942. Paris: Gallimard.)

Cederström, C. and Hoedemaekers, C. (2012) 'On dead dogs and unwritten jokes: Life in the university today’. Scandinavian Journal of Management, 28: 229-233.

Collini, S. (2012) What Are Universities For? London: Verso.

Collini, S. (2017) 'Voters should be enraged by higher education profiteering'. The Guardian 6 June (https://www.theguardian.com/education/2017/jun/06/higher-education-profiteeringtuition-fees-universities - accessed 7 June 2017).

Cornwell, N. (2006) The Absurd in Literature. Manchester: Manchester University Press.

Critchley, S. (1997) Very Little ... Almost Nothing: Death, Philosophy. London: Routledge.

Critchley, S. 2019 Tragedy, the Greeks, and Us. London: Profile Books

Davies, W. 2017 The Limits of Neoliberalism. Authority, Sovereignty and the Logic of Competition. London: Sage.

Davis, G.F. (2009) Managed by Finance. How Finance Re-Shaped America. Oxford: Oxford University Press.

Davis, G.F. (2015) 'Editorial essay: What is organizational research for?' Administrative Science Quarterly, 60: 179-188.

Debray, R. (2019) Civilization. How We All Became American. London: Verso.

Delves Broughton, P. (2008) What They Teach You at Harvard Business School. My Two Years Inside the Cauldron of Capitalism.London: Viking.

Elliott, C., Robinson, S. 2011 MBA imaginaries: projections of internationalization.

Management Learning 43: 157-181.

Esslin, M. (2001) The Theatre of the Absurd London: Methuen Drama. 
Faroohar, R. (2016) Makers and Takers. The Rise of Finance and the Fall of American Business. New York: Crown.

Ferraro, F., Pfeffer, J. and Sutton, R.L. (2005) 'Economic language and assumptions can become self-fulfilling'. Academy of Management Review, 30: 8-24.

Friedman, M. 1953 Essays in Positive Economics. Chicago: University of Chicago Press.

Gabriel, Y. (1995) 'The unmanaged organization: Stories, fantasies and subjectivity'. Organization Studies, 16: 477-501.

Gagliardi, P. \& Czarniawska, B. (eds.) 2006 Management Education and Humanities. Cheltenham: Edward Elgar.

Gagliardi, P. 2006 A role for humanities in the formation of managers. In Gagliardi, P. \& Czarniawska, B. (eds.) Management Education and Humanities. Cheltenham: Edward Elgar.

Ghoshal, S. 2005 Bad management theories are destroying good management practices. Academy of Management Learning \& Education 4: 75-91.

Goodman, N. (1978) Ways of Worldmaking. Indianapolis, IN: Hackett Publishing.

Greenblatt, S. 2018 Tyrant. Shakespeare on Politics. New York: W.W. Norton.

Grey, C. (2004) 'Reinventing business schools: The contribution of critical management education'. Academy of Management Learning and Education. 3: 178-186.

Hambrick, D. (1994) 'What if the Academy actually mattered?' Academy of Management Review, 19: 11-16.

Hendry, J. 2006 Educating managers for post-bureaucracy. The role of the humanities. Management Learning 37: 267-281.

Honderich, T. (1995) The Oxford Companion to Philosophy. Oxford: Oxford University Press.

Houillé, J.-E., Spillane, R. (2015) The Philosophical Assumptions of Management Thought. Lanham, Maryland: Lexington Books.

Hubbard, G. (2006) 'Business, knowledge and global growth'. Capitalism and Society ( https://doi.org/10.2202/1932-0213.1013 - accessed 1 November 2018).

Ionesco, F. (1958a) The Bald Soprano and Other Plays. New York: Grove Press.

Ionesco, E. (1958b) Amédée. The New Tenant. Victims of Duty New York: Grove Press.

Ionesco, E. (1960) Plays 3. London: Calder \& Boyars.

Ionesco, E. (1963) 'Notes on my theatre'. The Tulane Drama Review, 7 (3): 126-159. 
Ionesco, E. (1964) Notes and Counter Notes: Writings on the Theatre, New York: Grove Press.

Ionesco, E. (1972) 'Interview with Ionesco'. In Hayman, R. Eugène Ionesco. London: Heinemann.

Jouillié, J.-E., Spillane, R. (2015) The Philosophical Foundations of Management Thought. Lanham, Maryland: Lexington Books.

Kay, J. (2004) The Truth About Markets. London: Penguin.

Khurana, R. (2007) From Higher Aims to Hired Hands. The Social Transformation of American Business Schools and the Unfulfilled Promise of Management as a Profession.Princeton: Princeton University Press.

King, M. (2010) 'Mervyn King attacks 'absurd' bank risk'. BBC News 26 October (http://www.bbc.co.uk/news/business-11624994?print=true - accessed 26 October 2010).

Kirp, D.L. (2003) Shakespeare, Einstein and the Bottom Line. Cambridge, Mass.: Harvard University Press.

Koris, R., Örtenblad, A., Ojala, T. 2017 From maintaining the status quo to promoting free thinking and inquiry: Business student' perspective on the purpose of business school teaching. Management Learning 48: 174-186.

Kraft, B. (2012) Light between the Shadows. A Conversation with Eugene Ionesco. Mammoth Lakes, CA: Two Birds Press.

Lambrechts, F.J., Bouwen, R., Grieten, S., Huybrechts, J.P., Schein, E,H. (2011) Learning to help through humble inquiry and implications for management research, practice and education: An interview with Edgar Schein. Academy of Management Learning \& Education, 10: 131-147.

Lamont, R.C. (1993) Ionesco’s Imperatives. Ann Arbor: The University of Michigan Press.

Lane, N. (1994) Understanding Eugène Ionesco. Columbia: University of South Carolina Press.

Leavitt, H.J. (1989) 'Educating our MBAs: On teaching what we haven't been taught', California Management Review, 31, 3, 38-50.

McCabe, D. (2016) 'CCuriouser and curiouser': Organizations as Wonderland - a metaphorical alternative to the rational model'. Human Relations, 69: 945-973.

McDonald, D. (2017) The Golden Passport Harvard Business School, the Limits of Capitalism, and the Moral Failure of the MBA London: HarperBusiness.

March, J.G., Weil, T. (2005) On Leadership. Malden, MA: Blackwell Publishing. 
Moon, J. \& Orlitzky, M. (2011) Corporate social responsibility and sustainability education: a trans-Atlantic comparison. Journal of Management and Organization 17: 583-603.

Morgan, G. (2006) Images of Organization. Thousand Oaks, CA: Sage.

Murcia, M.J., Rocha, H.O., Birkinshaw, J. 2018 Business schools at the crossroads? Trip back from Sparta to Athens. Journal of Business Ethics150: 579-591.

Nussbaum, M. (1998) Cultivating Humanity. Classical Defence of Reform in Liberal Education. Cambridge, MA: Harvard University Press.

Parker, M. (2018) Shut Down the Business School: What's Wrong with Management Education. London: Pluto Press.

Peters, S. (2012) The Chimp Paradox. London: Vermilion.

Podolny, J.M. (2009) The buck stops 9and starts) at business school. Harvard Business Review 87 (7/8): 62-67.

Quiggin, M. (2012) Zombie Economics. How Dead Ideas Still Walk Among Us. Princeton: Princeton University Press.

Readings, B. 1997 The University in Ruins. Boston: Harvard University Press.

Reed, M., Burrell, G. 2018 Theory and organization studies: the need for contestation. Organization Studies 40: 39-54

Rodgers, D.T. 2011 Age of Fracture. Cambridge, Mass.: The Belknap Press of Harvard University Press.

Rorty, R. (1992) Contingency, Irony and Solidarity. Cambridge: Cambridge University Press.

Rorty, R. (1998) Achieving Our Country. Cambridge, MA: Harvard University Press.

Sartre, J.-P. (1960) 'Tribute to Albert Camus'. The Reporter Magazine, February 4, p.34. (http://faculty.webster.edu/corbetre/philosophy/existentialism/camus/sartre-tribute.html accessed 10 January, 2017).

Savage, P., Cornellisen, J.P., Franck, H. 2018 Fiction and organization studies. Organization Studies 39: 975-994.

Stigler, G.J. 1992 Law or economics? Journal of Law and Economics 35: 455-468.

Starkey, K. and Tiratsoo, N. 2007 The Business School and the Bottom Line. Cambridge: Cambridge University Press.

Styan J.L. (1968) The Dark Comedy. The Development of Modern Comic Tragedy. Cambridge: Cambridge University Press.

Tett, G. (2009) Fool's Gold. Little, Brown: London. 
Vargish, T. (1991) 'The value of humanities in executive development'. Sloan Management Review, 32: 83-91.

Wellmon, C. (2015) Organizing Enlightenment. Baltimore: Johns Hopkins University Press.

Willmott, H. (2011) 'Journal list fetishism and the perversion of scholarship: Reactivity and the ABS list'. Organization, 18: 429-442.

Woodward, A. (2009) Nihilism in Postmodernity. Lyotard, Baudrillard, Vattimo. Aurora, Colorado: Davies Group.

Žižek, S. (2010) Living in the End Times. London: Verso. 